Validation Study of the 10-item Connor-Davidson Resilience Scale Among Mexican Medical and Psychology Students

\title{
Estudio de Validación de la Escala de Resiliencia de Connor-Davidson de 10- ítems entre Estudiantes de Medicina y Psicología Mexicanos
}

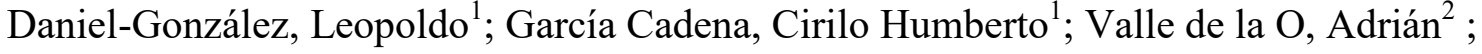 \\ Caycho-Rodriguez, Tomás ${ }^{3}$ y Martinez-Gómez,Enrique ${ }^{4}$
}

\begin{abstract}
Resumen:
Se determinó la estructura factorial, confiabilidad, validez convergente y discriminante, e invarianza factorial, de la escala de resiliencia CD-RISC-10. Los participantes fueron 330 estudiantes universitarios de medicina y psicología, con edad promedio de 20.20 años $(\mathrm{DE}=2.33)$. Los resultados obtenidos ratifican la estructura unidimensional de la escala $\left(\chi^{2} / \mathrm{gl}=3.06, \mathrm{GFI}=.93, \mathrm{CFI}=.92, \mathrm{NFI}=.90\right.$, $\mathrm{TLI}=.92$, RMSEA $=.08$ y SRMR $=.04)$, la invarianza factorial por tipo de estudiante y una buena consistencia interna $(\omega=.85$ y $\alpha=.85)$. Al comparar los niveles de resiliencia entre los estudiantes de medicina $(\mathrm{M}=20.64, \mathrm{DE}=4.48)$ y psicología $(\mathrm{M}$ $=20.27, \mathrm{DE}=4.51)$ se encontraron diferencias significativas $\left[\mathrm{t}_{(281)}=2.65, \mathrm{p}=.009, \mathrm{~d}=.20\right]$. Se obtuvieron evidencias de validez convergente y discriminante de la CD-RISC-10 con medidas de felicidad y estrés percibido. En conclusión, la CDRISC-10 presenta adecuadas propiedades psicométricas para medir la resiliencia en estudiantes universitarios mexicanos.
\end{abstract}

Palabras Clave: resiliencia; tamizaje; análisis factorial confirmatorio; invarianza factorial; estudiantes de medicina y psicología.

\begin{abstract}
:
The factorial structure, reliability, convergent and discriminant validity, as well as factorial invariance of the 10-item Connor-Davidson Resilience Scale (CD-RISC-10) were determined. The sample was composed of 330 students (174 medical students and 156 psychology students) with a mean age of 20.20 years $(S D=2.33)$. The results obtained confirm the unidimensional structure of the scale $\left(\chi^{2} / \mathrm{df}\right.$ $=3.06, \mathrm{GFI}=.93, \mathrm{CFI}=.92, \mathrm{NFI}=.90, \mathrm{TLI}=.92$, RMSEA $=.08$, and SRMR $=.04$ ), the factorial invariance with respect to career, and good internal consistency $(\omega=.85$ and $\alpha=.85)$. A statistically significant difference in the level of resilience between medical students $(\mathrm{M}=20.64, \mathrm{SD}=4.48)$ and psychology students $(\mathrm{M}=20.27, \mathrm{SD}=4.51)$ was found $\left[\mathrm{t}_{(281)}=2.65, \mathrm{p}=.009, \mathrm{~d}=.20\right]$. Evidence of convergent and discriminant validity of CD-RISC10 with happiness and perceived stress was obtained. It is concluded that CD-RISC-10 shows adequate psychometric properties to measure resilience in Mexican university students.
\end{abstract}

Keywords: resilience; screening; confirmatory factor analysis; factorial invariance; medical and psychology students.

\footnotetext{
${ }^{1}$ Facultad de Psicología. Universidad Autónoma de Nuevo León, México.

${ }^{2}$ Escuela de Medicina y Ciencias de la Salud. Instituto Tecnológico y de Estudios Superiores de Monterrey, México.

${ }^{3}$ Facultad de Psicología. Universidad Privada del Norte, Perú.

${ }^{4}$ Facultad de Medicina. Universidad Autónoma de Coahuila, México.
}

*Correspondencia: leopoldo.danielgn@uanl.edu.mx 
There exists a growing interest in studying positive psychological processes, such as resilience, coping, and optimal human functioning (Lent \& Brown, 2008). Until now, many studies have focused on assessing factors such as stress, anxiety, burnout, among others, and analyzing how these factors alter or negatively affect the mental health and/or productivity of people (Cuadra \& Florenzano, 2011); nevertheless, this pathogenic approach has been insufficient to help significantly improve their well-being and mental health. Positive psychology offers a relevant approach for such purpose, since it focuses on human strengths and virtues as well as on the favorable impact that they may have on the lives of people and society (Peterson, 2006).

Research on strengths has privileged different constructs (Ungar, 2008). Therefore, it is possible to find empirical literature on variables such as gratitude (Gillham et al., 2011), positive emotions (Fredrickson \& Joiner, 2019), optimism (García-Cadena et al., 2016; Marrero, González, \& Carballeira, 2014), happiness (Rodríguez-Hernández, 2019), and resilience (Armenta, Fritz, \& Lyubomirsky, 2017; Chen, 2016).

Resilience is a dynamic multidimensional construct that makes reference to a psychological strength that allows the individual to cope with and recover from adversity, and even to experience personal growth as a consequence of the misfortune experienced (Luthar, Cicchetti, \& Becker, 2000). Every individual possesses, to a different degree, this strength and it is through it that the individual manages to overcome stress and the challenges of life (Masten, 2007). The origins of the resilience construct are grounded in both the recognition that there exists a great diversity of coping responses towards adversity among individuals and the empirical evi- dence showing that some people show better results than others when experiencing comparable adverse situations. It has been shown that coping with unfavorable events may have either a sensitization effect through which the vulnerability of the individual to the negative effect of the stressor increases or, on the other hand, a strengthening effect through which the individual become immunized or toughened when faced with adversity (Rutter, 2012).

Resilience, in terms of human development, is defined in relation to adaptational success when facing a context of significant adversity (Cutuli, Herbers, Masten, \& Reed, 2018). In other words, it makes reference not just to the fact of surviving misfortune, a simple return to the previous baseline level of functioning, but to the enhancement of subsequent functioning owing to, and not in spite of, the experience of misfortune. Positive adaptation hence reflects that something has been gained (Linley, 2003). Thus, resilience may be conceptualized as a personal ability to weather adversity and it is a construct that may be assessed through self-report instruments (Davidson et al., 2005; Connor \& Davidson, 2003).

On the other hand, there are professions in which a higher number of stressors and greater levels of psychological stress are present (Monjezi \& Naderi, 2016). In the context of health sciences (for instance, medicine, nursing, psychology, among others), these kind of professionals are exposed to a great deal of occupational stress, so that it is necessary that they develop the capacity to control their emotions and cope with the environmental stressors in order to prevent these phenomena from interfering with their daily activities and avoid negative long-term health outcomes (Enns, Eldridge, Montgomery, \& Gon- 
zalez, 2018; Bacchi \& Licino, 2017; RuizAranda, Extremera, \& Pineda-Galán, 2014).

Nevertheless, according to Bouteyre, Maurel, and Bernaud (2007), attending university, in general, is considered a positive experience for students, although it is also true that, in many occasions, it is a period requiring major adjustments and learning new skills hence becoming a stressful experience. Likewise, many university students are transitioning from adolescence to adulthood and have also had to move away from their family home and networks of friends, thus requiring the ability to construct new social support networks as well as to meet the demands and/ or expectations coming from the university environment. They will also have to cope with multiple stressful situations, including academic ones, and this seems to be particularly significant among health sciences students (Cabanach, Souto-Gestal, \& Fernández, 2017). It is well known that pursuing a career in the field of health professions entails a great demand on students since there is a vast range of content and clinical skills that must be mastered and many adverse situations that students will have to face. These stressors not only do not decrease but tend to increase as they advance in their training (Faye et al., 2018). This situation may lead to increased likelihood of depressive mood, anxiety, sleep disorders, high level of perceived stress, fatigue, burnout, empathy decline, decreased professionalism, as well as to the use of alcohol, tobacco or other substances (medication/ drugs) as a strategy for coping distress, and even to abandonment of their dream of pursuing a career on health sciences (Farquhar, Kamei, \& Vidyarthi, 2018; Houpy, Lee, Woodruff, \& Pincavage, 2017).

In relation to the above, Medina-Mora et al. (2003) found that younger populations have presented the higher rates of depression or another mental disorder and half of the cases occur in people before the age of 21 years (Wagner et al., 2012). A study performed in Mexico with university students found that $13 \%$ of the sample studied showed symptoms of anxiety and depression (Galván-Molina, Jiménez-Capdeville, Hernández-Mata, \& Arellano-Cano, 2017). A study carried out with students from health sciences in Mexico found evidence that medical students had the highest levels of depression and suicidal ideation (Coffin, Alvaréz, \& Marín, 2011). Another study in Mexico with university students who attended mental health services found that $58.7 \%$ had a prevalence of depression and $50.3 \%$ suicidal risk (Cotonieto-Martínez, Crespo-Jiménez, Valencia-Ortíz, \& GarcíaCruz, 2019). Finally, in a study conducted with Mexican psychology students it was found that the $84.51 \%$ had slight symptoms of academic burnout (Barradas, Trujillo, Sanchez, \& López, 2017).

On the other hand, there are few studies about resilience among university students (Vizoso-Gómez \& Arias-Gundín, 2018), although there is some research carried out on students from Mexican universities (González -Arratia \& Valdez, 2013; González-Arratia \& Valdez, 2012). It is possible that one of the obstacles to resilience research in academic areas is the lack of work on validation of instruments to assess resilience. There are several scales to measure resilience in Mexico, such as the Resilience Questionnaire (Strength and Personal Security) (GonzálezArratia, Valdez, \& Zavala, 2008), the Mexican Resilience Scale (Palomar \& Gómez, 2010) or the Scale of Potential Resources for Resilience for Adolescents (Barcelata \& Rodríguez, 2016); however, these instruments are extensive (between 43 and 86 items), a fact that may hinder its application. Thus, the validation of the reduced version of the Con- 
nor-Davidson Resilience Scale, originally used to measure resilience in university students in the United States of America by Campbell-Sills and Stein (2007), is proposed.

Even though abbreviated versions of scales are useful and desirable when researchers need to assess several psychological variables in a short amount of time, Widaman, Little, Preacher, and Sawalini (2011) have commented that an important shortcoming of these brief forms of scales is that they usually have poorer psychometric properties than the original long form of instrument. Nevertheless, John and Soto (2007) have highlighted that lengthy scales may induce fatigue in the respondents and, consequently, less reliable responses. As will be seen later, the findings of this research show that CD-RISC-10 is a valid and reliable scale.

On the other hand, there exist several translations of CD-RISC-10, for example in Spain (Notario-Pacheco et al., 2011), Brazil (Lopes \& Martins, 2011), China (Ye et al., 2017), among others (Tourunen, Siltanen, Saajanaho, Koivunen, \& Kokko, 2019; Munévar, Vargas, Borda, Alpi, \& Quiceno, 2017). Nevertheless, owing to the linguistic and cultural differences that, there exist in different populations in spite of the fact that those populations speak the same language, it has been recommended to adapt the instruments to the concrete regional context in which they will be applied so as to ensure the semantic, idiomatic, and experiential equivalence of the items composing any given scale. Let's suppose, for instance, that an instrument intended to assess a given psychological construct has been translated and adapted to be used, let us say, in Spain. The relevance of some of the items composing the scale might not be the same to a Mexican population or to a Colombian population, and even some sentences might need to be reworded in order to con- form to the local popular Spanish as spoken in Mexico or Colombia. That is why it is important to conduct a judicious process of translation and adaptation of an instrument intended to assess any psychological construct in order to maintain the content validity of the instrument and ensure linguistic equivalence and relevance in a particular social, cultural, or regional context (Navarro-Mateu et al., 2013).

The justification for this study is based on the lack of research about the validation and adaptation of scales in the Mexican context and on the need to assess resilience among medical and psychology students through a brief and reliable scale, given the stressful characteristics of studying a career within the field of health sciences (Faye et al., 2018; Houpy et al., 2017). Based on the aforementioned, the aims of this research are: 1) to analyze the factorial structure of CD-RISC$10,2)$ to determine its factorial invariance according to the studied career, 3 ) to estimate the reliability of CD-RISC-10,4) to show evidence of convergent and discriminant validity for CD-RISC-10, and 5) to compare the levels of resilience using the Mexican version of CD -RISC-10 in a sample of Mexican medical and psychology students.

\section{Method \\ Participants and Procedure}

An incidental sample comprising university students was collected (since the sample was non-probabilistic, no criteria were considered to determine the sample size). In order to participate in the study, it was necessary to be an active psychology or medical student. The only exclusion criteria were not to be a student of the aforementioned careers.

The sample was composed of 330 university students (118 men and 212 women) aged from 17 to 36 years $(\mathrm{M}=20.22, \mathrm{SD}=$ 
2.27) were recruited from three universities located in northeast Mexico. The participants were studying either medicine $(n=174)$ at a private university or psychology $(n=156)$ at a public university, and most of them were single $(n=324,98.2 \%)$. The mean age of the medical (82 men and 92 women) and psychology (36 men and 120 women) students was 20.09 years $(S D=2.13)$ and 20.38 years $(S D$ $=2.42$ ). Respectively, no statistically significant difference on age between the two groups were found $\left[\mathrm{F}=4.01, \mathrm{p}=.04, \mathrm{t}_{(310.42)}=\right.$ $-1.16, \mathrm{p}=.24, \mathrm{~d}=.09$, CI 95\% $(.79, .20)]$. The age did not show adjustment to normal distribution $(\mathrm{KSL}=.20, \mathrm{p}<.001)$.

The original English version of CD-RISC-10 was translated into Spanish and then back translated into English in order to fulfill the international criterion for back translation recommended by Muñiz and Hambleton (1996). The original test was translated into Spanish by two bilingual psychologists whose mother tongue was Spanish. A bilingual (in English and Spanish) expert familiar with terminology reviewed the translation in order to resolve any inadequate expression. Then, the Spanish version generated in this way was sent to another two bilingual psychologist whose mother tongue was English and who were asked to translate the scale back to English. Subsequently, after completing the process of back translation, the next step was to compare the back translation with the original version in order to determine whether or not there were any significant difference between the two versions and to reconcile those differences case they were present. Finally, the linguistic equivalence of the scale was determined in consensus and the scale was pretested on a sample composed of members of the target population. The final version of $\mathrm{CD}$ -RISC-10 in the target language was the result of all the iterations described above.

Before applying the tests, permission was requested from the corresponding academic authorities of each university. The students of medicine and psychology were invited to participate voluntarily in the study and were also asked to sign the corresponding informed consent. After explaining the objective of the investigation and giving the necessary information, the questionnaires collectively administered in their classrooms. No economic, material or academic stimulus was given for participating in this research. No identification data were asked for to the participants in order to assure their anonymity, and the confidentiality of the information provided through this questionnaire was guaranteed.

The application of the test was carried out in the classrooms. In order to get the whole sample, 20 sessions were needed. The average response time to the test was 10 minutes.

\section{Measures}

10-Item Connor-Davidson Resilience Scale (CD-RISC-10; Campbell-Sills \& Stein, 2007). It is a self-report instrument composed of ten items that are evaluated along a sixpoint, Likert-type scale (from $0=$ never to $5=$ always). The sum of these items yields a total score such that the higher the score, the higher the level of resilience. CD-RISC-10 showed a unidimensional structure and a good internal consistency $(\alpha=.85)$.

Subjective Happiness Scale (SHS; Lyubomirsky \& Lepper, 1999). It is a self-report instrument composed of four items that are evaluated along a seven-point, Likert-type scale. The sum of these items yields a total score such that the higher the score, the higher the level of happiness. The scale was used in order to show evidence of convergent validity for CD-RISC-10, because happiness and resilience are theoretically and empirically related (Cohn, Fredrickson, Brown, Mikels, \& Conway, 2009). In the present study, SHS showed an acceptable internal consisten- 
cy $(\alpha=.72$ and $\omega=.76)$. The Spanishlanguage version of SHS used in this study was developed by Quezada, Landero, and González (2016).

Perceived Stress Scale (PSS; Cohen et al., 1983). It is a self-report instrument composed of 14 items that are evaluated along a six-point, Likert-type scale. The sum of these items yields a total score such that the higher the score, the higher the level of perceived stress. The scale was used with the aim of showing discriminant validity for CD-RISC10 , because perceived stress and resilience are theoretically and empirically related (Abolghasemi \& Taklavi-Varaniyab, 2010).

In the present study, PSS showed a good internal consistency $(\omega=.76$ and $\alpha$ $=.87$ ). The Spanish-language version of PSS used in this study was developed by González and Landero (2007).

\section{Statistical Analysis}

The descriptive statistics (mean, standard deviation, asymmetry, kurtosis, and inter-item correlations) of the scores of the items composing CD-RISC-10. The assumption of multivariate normality was assessed through Mardia's multivariate kurtosis coefficient; this assumption is fulfilled if its value is $\leq 70$ (Rodriguez \& Ruiz, 2008).

Before performing factor analysis, the Kaiser-Meyer-Olkin (KMO) test for sampling adequacy was assessed; a value higher than .60 is considered adequate. Likewise, it is necessary to reject the null hypothesis of equivalence of the correlation matrix to an identity matrix through the Bartlett's test of sphericity; small values $(<.05)$ of the significance level indicate that factor analysis may be performed.

Confirmatory factor analysis (CFA) was used to validate the one-factor structure of CD-RISC-10. CFA was executed based on maximum likelihood estimation method. The goodness of fit of the model was estimated through the relative chi-square $\left(\chi^{2} / \mathrm{df}\right)$, Goodness of Fit Index (GFI), Comparative Fit Index (CFI), Normed Fit Index (NFI), TuckerLewis Index (TLI), Root Mean Square Error of Approximation (RMSEA), and Standardized Root Mean Square Residual (SRMR). The following criteria were stipulated for defining an adequate goodness of fit: $\chi^{2} / \mathrm{df} \leq 3$, GFI, CFI, NFI, and TLI $\geq .90$, RMSEA $\leq .08$, and $\mathrm{SRMR} \leq .10$ (Byrne, 2016).

The convergent validity of the factor was determined [measurement weights ( $\lambda$ $\geq .40$ ) and average variance extracted (AVE $\geq$.19) for ten indicators] (Moral, 2019).

Several criteria were taken into account in order to determine if CD-RISC-10 was invariant across medical and psychology students. First, the Tucker-Lewis Index (TLI) should reach a value greater than .90 . Subsequently, the invariance was tested through the calculation of nested models with imposition of sequential constraints upon de unconstrained model: unconstrained model (M 1), constrained in factor loadings (M 2), constrained in structural variances/covariances (M 3), and constrained in measurements residuals (M 4). The evaluation of the difference among the four proposed models was carried out through Comparative Fit Index (CFI; $\Delta \mathrm{CFI}$ ), and Root Mean Square Error of Approximation (RMSEA; $\triangle$ RMSEA). Factorial invariance is assumed if $\triangle \mathrm{CFI} \leq .01$ and $\triangle \mathrm{RMSEA} \leq .015$ (Byrne, 2016).

The evidence for convergent and discriminant validity was calculated through Pearson's coefficient between the scores of CDRISC-10 and other measures that are theoretically related to resilience.

The student's t-test for independent samples was carried out in order to compare the levels of resilience between medical and 
psychology students. The estimation of the reliability of the scores of CD-RISC-10 was expressed by Cronbach's alpha with its confidence intervals and McDonald's omega. Values for $\alpha \geq .70$ and $\omega \geq .80$ are expected. Statistical calculations were executed through IBM SPSS v24 and AMOS v24.

\section{Results}

\section{Descriptive Statistics of the Items Compos- ing CD-RISC-10}

Table 1 shows the descriptive statistics (mean, standard deviation, skewness, and kurtosis) and the inter-item correlations of CDRISC-10. Item six showed the highest mean score $(M=3.98, S D=.96)$ and item eight the lowest $(M=2.70, S D=1.31)$. None of the items composing the scale presented excessive skewness or kurtosis $(\leq \pm 1.5)$. The value of the Mardia's coefficient was 15.45, which provides evidence for the fulfillment of multivariate normality assumption.

The $K M O$ value was .89 and Bartlett's test of sphericity was significant $\left[\chi_{(45)}^{2}=\right.$ $1014.92, d f=45, p<.001]$, it was proceeded to perform directly CFA (Suhr, 2006).

\section{Confirmatory Factor Analysis (CFA)}

For performing CFA, the ten items of the CDRISC-10 were considered as a single latent variable. The goodness-of-fit indices showed that the unifactorial model correctly fitted the data. $\left[\chi^{2}=95.63\right.$, df $=35, \mathrm{p}<.001, \chi^{2} / \mathrm{df}=$ 2.73, GFI $=.95, \mathrm{CFI}=.94, \mathrm{NFI}=.91$, TLI $=.92$, RMSEA $=.07,90 \%$ CI $(.06, .09)$, and SRMR $=.044]$. The standardized $\lambda$ 's were significant and positive (I1 $=.62, \mathrm{I} 2=.77, \mathrm{I} 3$ $=.61, \mathrm{I} 4=.56, \mathrm{I} 5=.61, \mathrm{I} 6=.70, \mathrm{I} 7=.46$, I8 $=.41, \mathrm{I} 9=.64$, and $\mathrm{I} 10=.66)$. The inter-item correlations of the CD-RISC-10 (see table 1) are not greater than .90 , so that there exists no multicollinearity and the items composing CD -RISC-10 are not redundant and showed internal discriminant validity (Tabachnick \& Fidell, 2019). The value of the average variance extracted $(\mathrm{AVE}=.38)$ was greater than the minimum required, therefore it is possible to affirm that the measurement model has convergent internal validity.

\section{Table 1.}

Descriptive statistics and inter-item correlations of CD-RISC-10

\begin{tabular}{|c|c|c|c|c|c|c|c|c|c|c|c|c|c|c|}
\hline \multirow[t]{2}{*}{ Item } & \multirow[t]{2}{*}{$M$} & \multirow[t]{2}{*}{$S D$} & \multirow[t]{2}{*}{$S k$} & \multirow[t]{2}{*}{$K$} & \multicolumn{10}{|c|}{ Inter-item correlation } \\
\hline & & & & & I1 & $\mathrm{I} 2$ & $\mathrm{I} 3$ & I4 & I5 & I6 & I7 & I8 & I9 & $\mathrm{I} 10$ \\
\hline I1 & 3.92 & .98 & -.94 & .99 & 1 & $.60^{*}$ & $.36^{*}$ & $.31^{*}$ & $.36^{*}$ & $.41^{*}$ & $.32^{*}$ & $.21^{*}$ & $.33^{*}$ & $.35^{*}$ \\
\hline $\mathrm{I} 2$ & 3.87 & .90 & -.82 & 1.10 & - & 1 & $.44^{*}$ & $.42^{*}$ & $.48^{*}$ & $.54^{*}$ & $.30^{*}$ & $.26^{*}$ & $.47^{*}$ & $.49^{*}$ \\
\hline $\mathrm{I} 3$ & 3.80 & 1.09 & -.70 & .02 & - & - & 1 & $.41^{*}$ & $.40^{*}$ & $.47^{*}$ & $.32^{*}$ & $.21^{*}$ & $.40^{*}$ & $.39^{*}$ \\
\hline I4 & 3.56 & 1.16 & -.55 & -.23 & - & - & - & 1 & .47 & $.35^{*}$ & $.28^{*}$ & $.22^{*}$ & $.34^{*}$ & $.32^{*}$ \\
\hline I5 & 3.65 & 1.10 & -.62 & -.16 & - & - & - & - & 1 & $.41^{*}$ & $.31^{*}$ & $.25^{*}$ & $.34^{*}$ & $.37^{*}$ \\
\hline I6 & 3.98 & .96 & -.80 & .22 & - & - & - & - & - & 1 & $.36^{*}$ & $.25^{*}$ & $.49^{*}$ & $.42^{*}$ \\
\hline I7 & 3.42 & 1.19 & -.58 & -.12 & - & - & - & - & - & - & 1 & $.22^{*}$ & $.26^{*}$ & $.32^{*}$ \\
\hline I8 & 2.70 & 1.31 & -.08 & -.59 & - & - & - & - & - & - & - & 1 & $.29^{*}$ & $.39^{*}$ \\
\hline I9 & 3.88 & 1.06 & -.81 & .25 & - & - & - & - & - & - & - & - & 1 & $.55^{*}$ \\
\hline I10 & 3.61 & 1.10 & -.66 & .13 & - & - & - & - & - & - & - & - & - & 1 \\
\hline
\end{tabular}

Notes. ${ }^{*} p<.01, M=$ mean, $S D=$ standard deviation, $S k=$ Skewness, and $K=$ Kurtosis 
Factorial Invariance of CD-RISC-10 Between Medical and Psychology Students The global goodness-of-fit indices of the unidimensional model for the whole sample are shown in table 2. Since the value of the TLI was .92, it was proceeded to perform the analysis of factorial invariance.

Firstly, the structure of CD-RISC-10 among medial and psychology students was revised $\left(\mathrm{M}_{1}\right)$ and good goodness-of-fit indices were obtained $[G F I=.92, C F I=.93, S R M R$ $=.06$, and $R M S E A=.06,90 \%$ CI $(.04, .07)]$; significant factor loadings were also reached $(p<.001)$.

Second, model $\mathrm{M}_{1}$ was used as a reference to test the model $\mathrm{M}_{2}$, in which the factor loadings are the same in both groups. The results showed good goodness of fit $[G F I=.92$, $C F I=.93, S R M R=.065$, and $R M S E A=.05$, $90 \% C I(.04, .06)]$. When performing the comparison between models $\mathrm{M}_{2}$ and $\mathrm{M}_{1}$, no significant changes were found $(\triangle C F I=.000$ and $\triangle R M S E A=.009)$. This suggests that factor loadings are invariant among medical and psychology students.
As a third step, model $\mathrm{M}_{3}$, in which the factor loadings and intercepts are the same among medical and psychology students, was assessed. The results showed that model $\mathrm{M}_{3}$ has adequate goodness-of-fit indices [ $G F I=$ 92, $C F I=.93, S R M R=.07$, and RMSEA $=.05,90 \% C I(.04, .06)]$. Upon comparing models $\mathrm{M}_{2}$ and $\mathrm{M}_{3}$, no significant changes were found $(\triangle C F I=.000$ and $\triangle R M S E A$ $=.000)$. Thus, empirical evidence for invariance in the model with restrictions in structural variances and covariances was found.

Finally, model $\mathrm{M}_{4}$, in which the factor loadings, intercepts, and residuals are invariant in both groups, was analyzed. The results showed that model $\mathrm{M}_{4}$ has good goodness-offit indices $[G F I=.90, C F I=.92, S R M R$ $=.07$, and $R M S E A=.05,90 \%$ CI $(.05, .07)]$. Upon comparing models $\mathrm{M}_{3}$ and $\mathrm{M}_{4}$, no significant differences were found $(\triangle C F I=.01$ and $\triangle R M S E A=.003)$. These results validate the hypothesis of invariance in the model with restrictions in measurement residuals.

All the results informed above allow to assert the factorial invariance of CD-RISC10 across medical and psychology students.

Table 2.

Internal structure and factorial invariance of CD-RISC-10

\begin{tabular}{|c|c|c|c|c|c|c|c|c|c|}
\hline Model & $\chi^{2}(d f)$ & $\begin{array}{l}\Delta \chi^{2} \\
(\Delta d f)\end{array}$ & $\begin{array}{c}R M S E A \\
{[90 \% \mathrm{CI}]}\end{array}$ & $p$ & SRMR & GFI & $C F I$ & $(\triangle C F I)$ & $(\triangle R M S E A)$ \\
\hline Both groups & $\begin{array}{l}2.73 \\
(35)\end{array}$ & - & $\begin{array}{c}.07 \\
{[.06, .09]}\end{array}$ & .000 & .04 & .95 & .94 & - & - \\
\hline Medicine & $\begin{array}{l}1.37 \\
(35)\end{array}$ & - & $\begin{array}{c}.09 \\
{[.08, .01]}\end{array}$ & .000 & .06 & .90 & .88 & - & - \\
\hline Psychology & $\begin{array}{l}2.01 \\
(35)\end{array}$ & - & $\begin{array}{c}.05 \\
{[.00, .08]}\end{array}$ & .000 & .04 & .94 & .97 & - & - \\
\hline $\mathrm{M}_{1}$ & $\begin{array}{l}2.03 \\
(70)\end{array}$ & - & $\begin{array}{c}.06 \\
{[.04, .07]}\end{array}$ & .000 & .06 & .92 & .93 & - & - \\
\hline $\mathrm{M}_{2}$ & $\begin{array}{l}1.84 \\
(79)\end{array}$ & $\begin{array}{l}.19 \\
(9)\end{array}$ & $\begin{array}{c}.05 \\
{[.04, .06]}\end{array}$ & .000 & .07 & .92 & .93 & .000 & .010 \\
\hline $\mathrm{M}_{3}$ & $\begin{array}{l}1.83 \\
(80)\end{array}$ & $\begin{array}{l}.01 \\
(1)\end{array}$ & $\begin{array}{c}.05 \\
{[.04, .07]}\end{array}$ & .000 & .07 & .92 & .93 & .000 & .000 \\
\hline $\mathrm{M}_{4}$ & $\begin{array}{l}1.97 \\
(90)\end{array}$ & $\begin{array}{r}.14 \\
(10) \\
\end{array}$ & $\begin{array}{c}.05 \\
{[.04, .07]}\end{array}$ & .000 & .07 & .90 & .92 & .010 & .003 \\
\hline
\end{tabular}

Notes. $\mathrm{M}_{1}=$ without restrictions, $\mathrm{M}_{2}=$ with restrictions in measurement weights, $\mathrm{M}_{3}=$ with restrictions in structural variances and covariances, and $\mathrm{M}_{4}=$ with restrictions in measurement residuals 
Comparison of Mean on CD-RISC-10 Scores Between Medical and Psychology Students

After verifying the factorial invariance, the mean scores on CD-RISC-10 of medical students $(M=37.48, S D=6.53)$ and psychology students $(M=35.12, S D=7.35)$ were compared. The results showed a statistically significant difference on resilience between medical and psychology students $\left[t_{(328)}=\right.$ $3.01, p=.002, d=.20]$ with a small effect size.

\section{Convergent and Discriminant Validity}

The correlations of CD-RISC-10 with the SHS and the PSS were examined. The correlation between resilience and happiness was positive $[r=.511, p=.000(95 \% C I .44, .78)]$ and between resilience and perceived stress was negative $[r=-.582, p=.000(95 \%$ $C I .50, .65)]$. Both relations were statistically significant, showed the expected direction, and had a moderate in magnitude.

\section{Reliability of CD-RISC-10}

The reliability of CD-RISC-10 with reference to measurement weights $(\lambda)$ was good

$(\omega=.85)$ and with allusion to variance was also good $(\alpha=.85)$. Therefore, CD-RISC-10 can be considered as a reliable instrument.

\section{Discussion}

The objective of the present research was to examine the factorial structure, factorial invariance, and reliability of the Mexican version of CD-RISC-10. Considering the results that have been obtained, it is possible to assert that CD-RISC-10 is a reliable, short measurement of resilience which can be used for research purposes as a screening test of resilience among university students.
The results confirm the unidimensional structure of CD-RISC-10, which is consistent with what was originally stated in samples from the United States, Spain, China, as well as Brazil. The results offer enough empirical support to assert that CD-RISC-10 measures a single latent trait, thus fulfilling an important requirement for a measurement instrument (Wilson, 2005).

It is worth noting that the present research is the first one to study the factorial invariance of CD-RISC-10 as a function of the career studied by the students. The invariance without restrictions, with restrictions in factor loadings, with restrictions in structural variances and covariances, and with restrictions in measurement residuals was maintained when comparing the groups. This fact indicates that the items composing CDRISC-10 similarly measure the same latent variable (Brown, 2015).

From a psychometric perspective, the factorial invariance is a prerequisite for any comparison between groups (Byrne, 2016). The data obtained in this research support the invariance of the unidimensional structure of CD-RISC-10 across medical and psychology students and, therefore, it is possible to assert that the medical and psychology students that have been enrolled in this study understand the resilience construct in the same way; in other words, these students interpret and respond to the items composing CD-RISC-10 in a similar fashion. In addition, a statistically significant difference was found in the mean of the scores of CD-RISC-10 between medical and psychology students, allowing to assert that this difference indicates a true divergence in the latent variable and is not the result of a measurement bias.

The differences found on the levels of resilience between medical and psychology 
students could be explained by differences in teaching methods, styles of learning, personality traits and cultural factors (Vaughn, Gonzalez, \& Baker, 2001). Students must adapt to their new living conditions and deal with different teaching style and with their own responsibilities; thus, the beginning of university life demands an adaptive period that may have a negative impact on the mental health of the students (Bouteyre et al., 2007).

It is well known that the medical career is characterized by its complexity, strict teachers, as well as by the need to face high stress situations (Fares et al., 2016). Thus, it is possible that the fact of having to deal with highly stressful situations and a high academic load, leads indirectly the medical students to develop a personal growth, which could explain their higher levels of resilience, although it should be noted that their level of resilience is not very much greater than the level of resilience found among the psychology students.

In order to provide evidence of convergent and discriminant validity, the correlation between CD-RISC-10, happiness and perceived stress was examined. Happiness is positively related to resilience, and negatively to perceived stress, being these results similar to the findings in previous studies (Smith \& Yang, 2017; Lü, Wang, Liu, \& Zhang, 2014; Souri \& Hasanirad, 2011; Clark \& Senik, 2011; Tugade, Fredrickson, \& Barrett, 2004; Connor \& Davidson, 2003). These results suggest that resilience is associated with the perception of happiness, which is an important variable for the achievement of a full and meaningful life in which the stressful situations of personal and academic life can be adequately addressed. These findings are important from a practical point of view, since a decrease in resilience could be explained by a low level of happiness and a high level of perceived stress.

With regard to reliability, the values obtained are indicative of the similarity (homogeneity) of the items (Muñiz, 1999). The values of Cronbach's alpha (between .82 and .87) are coincident in the validation studies conducted in the United States, Spain, China and Brazil. On the other hand, the values of the reliability coefficients of the present study are higher than those reported in Brazil $(\alpha=.82)$ and American university students $(\alpha=.83)$, but lower than the coefficient reported in China $(\alpha=.87)$. The results found in this research are those desired for brief screening instruments, and for research (Dominguez-Lara \& Merino-Soto, 2017).

A limitation of this study was the accessibility, only medical students from private universities were enrolled in this research. Nonetheless, in the case of psychology students, it was possible to have access to both a private and a public university. In this sense, it would be useful to increase the number of participants and broaden the scope to include students of different careers in order to find out if the results presented here are replicable. Likewise, a convenience sample was used, which makes it difficult to generalize the results. Another limitation was that a crosssectional design was used; nevertheless, longitudinal studies would be necessary in order to provide a greater evidence of predictive and/or explanatory validity. Finally, testretest reliability was not explored in this study.

The results that have been informed in this research allow to conclude that the Mexican version of CD-RISC-10 shows good psychometric properties for the measurement of resilience among medical and psychology students. However, it is necessary to continue 
performing psychometric studies in different populations. Likewise, the CD-RISC-10 is invariant among medical and psychology students. Future research should advance in the study of the factorial invariance of the CDRISC-10 (for instances, across sex, age groups, among other variables), in order to guarantee the comparability and equivalence of the resilience construct. Owing to its rapid and easy administration, CD-RISC-10, as a self-report measure, represents a great advantage in large-scale studies, which represent a promising line of research.

\section{References}

Abolghasemi, A., \& Taklavi-Varaniyab, S. (2010). Resilience and perceived stress: Predictors of life satisfaction in the students of success and failure. Procedia - Social and Behavioral Sciences, 5, 748-752. doi: 10.1016/j.sbspro.2010.07.178

Armenta, C. N., Fritz, M. M., \& Lyubomirsky, S. (2017). Functions of positive emotions: Gratitude as a motivator of self-improvement and positive change. Emotion Review, 9(3), 183-190. doi: $10.1177 / 1754073916669596$

Bacchi, S., \& Licinio, J. (2017). Resilience and psychological distress in psychology and medical students. Academic Psychiatry, 41(2), 185-188. doi: 10.1007/s40596-016-0488-0

Barradas, M., Trujillo, P., Sanchez, A., \& López, J. (2017). Student burnout in Veracruz university students. Revista Iberoamericana para la Investigación y el Desarrollo Educativo, 7(14), 1-19. doi: 10.23913/ride.v7i14.267

Barcelata, B. E., \& Rodríguez, R. (2016). Desarrollo y validación de la escala de recursos potenciales para la resiliencia para adolescentes. Revista Latinoamericana de Medicina Conductual, 6(2), 75-87.

Bouteyre, E., Maurel, M., \& Bernaud, J. L. (2007). Daily hassles and depressive symptoms among first year psychology students in France: The role of coping and social support. Stress and Health, 23(2), 93-99. doi: 10.1002/smi.1125

Brown, T. A. (2015). Confirmatory Factor Analysis for Applied Research ( $2^{\text {nd }}$ Ed.). New York: Guilford Press.

Byrne, B. M. (2016). Structural Equation Modeling with AMOS Basic Concepts, Applications, and Programming ( $3^{\text {rd }}$ Ed.). New York: Routledge. doi: 10.4324/9781315757421

Cabanach, R. G., Souto-Gestal, A., \& Fernández, R. (2017). Perfiles de regulación emocional y estrés académico en estudiantes de fisioterapia. European Journal of Education and Psychology, 10 (2), 57-67. doi: 10.1016/j.ejeps.2017.07.002

Campbell-Sills, L., \& Stein, M. (2007). Psychometric analysis and refinement of the Connor-Davidson Resilience Scale (CD-RISC): Validation of a 10item measure of resilience. Journal of Traumatic Stress, 20(6), 1019-1028. doi: 10.1002/jts.20271

Chen, C. (2016). The role of resilience and coping styles in subjective well-being among chinese university students. Asia-Pacific Education Researcher, 25(3), 377-387. doi: 10.1007/s40299016-0274-5

Clark, E., \& Senik, C. (2011). Is happiness different from flourishing? Cross-country evidence from the ESS. Revue d'économie Politique, 121(1), 17 -34. doi: 10.3917/redp.211.0017

Cohen, S., Kamarck, T., Mermelstein, R., Health, J., Behavior, S., \& Dec, N. (1983). A global measure of perceived stress. Journal of Health and Social Behavior, 24(4), 385-396. doi: $10.2307 / 2136404$

Cohn, M. A., Fredrickson, B. L., Brown, S. L., Mikels, J. A., \& Conway, A. M. (2009). Happiness unpacked: Positive emotions increase life satisfaction by building resilience. Emotion, 9(3), 361368. doi: $10.1037 / \mathrm{a} 0015952$

Coffin, N., Alvaréz, M., \& Marín, A. (2011). Depresión e ideación suicida en estudiantes de la FESI: Un estudio piloto. Revista Electrónica de Psicología Iztacala, 14(4), 341-354.

Connor, K. M., \& Davidson, J. R. T. (2003). Development of a new resilience scale: The ConnorDavidson Resilience Scale (CD-RISC). Depression and Anxiety, 18(2), 76-82. doi: 10.1002/ da. 10113

Cotonieto-Martínez E., Crespo-Jiménez, K. F., Valencia-Ortiz, A. I., \& García-Cruz, R. (2019). Mental health among college users of mental health services: Suicide risk screening and prevention strategies. Journal of Negative and No Positive Results, 5(2), 167-79. doi: 10.19230/jonnpr.3234

Cuadra L. H., \& Florenzano U. R. (2011). El bienestar subjetivo: Hacia una psicología positiva. Revista de Psicología, 12(1), 83-96. doi: 10.5354/07190581.2003 .17380

Cutuli, J. J., Herbers, J. E., Masten, A. S. \& Reed, M. 
G. J. (2018). Resilience in development. In C. R. Snyder., S. J. Lopez., L. M. Edwards., \& S. C. Marques (Eds.), The Oxford Handbook of Positive Psychology ( ${ }^{\text {rd }}$ Ed.). New York: Oxford University Press. doi: 10.1093/ oxfordhb/9780199396511.013.9

Davidson, J. R., Payne, V. M., Connor, K. M., Foa, E. B., Rothbaum, B. O., Hertzberg, M. A., \& Weisler, R. H. (2005). Trauma, resilience, and allostasis: Effects of treatment in post-traumatic stress disorder. International Clinical Psychopharmacology, 20(1), 43-48.

Domínguez-Lara, S. A., \& Merino-Soto, C. (2017). Versión breve de la escala de afrontamiento ante la ansiedad e incertidumbre preexamen (COPEAU) en universitarios peruanos. Educación Médica, 19(2), 67-72. doi: 10.1016/ j.edumed.2017.04.011

Enns, A., Eldridge, G. D., Montgomery, C., \& González, V. M. (2018). Perceived stress, coping strategies, and emotional intelligence: A crosssectional study of university students in helping disciplines. Nurse Education Today, 68, 226231. doi: 10.1016/j.nedt.2018.06.012

Extremera, N., Durán, A., \& Rey, L. (2007). Perceived emotional intelligence and dispositional optimism-pessimism: Analyzing their role in predicting psychological adjustment among adolescents. Personality and Individual Differences, 42, 1069 -1079. doi: 10.1016/j.paid.2006.09.014

Fares, J., Tabosh, H., Saadeddin, Z., El Mouhayyar, C., \& Aridi, H. (2016). Stress, burnout and coping strategies in preclinical medical students. North American Journal of Medical Sciences, 8(2), 7581. doi: 10.4103/1947-2714.177299

Farquhar, J., Kamei, R., \& Vidyarthi, A. (2018). Strategies for enhancing medical student resilience: Student and faculty member perspectives. International Journal of Medical Education, 9, 1-6. doi: 10.5116/ijme.5a46.1ccc

Faye, A., Tadke, R., Gawande, S., Kirpekar, V., Bhave, S., Pakhare, A., Singh, D., \& Nadpara, J. (2018). Assessment of resilience and coping in undergraduate medical students: A need of the day. Journal of Education Technology in Health Sciences, 5(1), 36-44. doi: 10.18231/23938005.2018.0008

Fredrickson, B. L., \& Joiner, T. (2018). Reflections on positive emotions and upward spirals. Perspectives on Psychological Science, 13(2), 194-199. doi: 10.1177/1745691617692106

Galván-Molina, J. F., Jiménez-Capdeville, M. E., Hernández-Mata, J. M., \& Arellano-Cano, J. R. (2017). Sistema de tamizaje de psicopatología en estudiantes de medicina. Gaceta Medica de México, 153, 75-87.

García-Cadena, C., Téllez, A., Ramírez, G., Ramírez, E., \& Pérez, E. (2016). Toward a Global Conceptualization and Measurement in Positive Psychology. In R. Bowers (Ed.), Psychological Well -Being. Cultural Influences, Measurement Strategies and Health Implications (pp. 21-42). New York: Nova Science Publisher.

Gillham, J., Adams-Deutsch, Z., Werner, J., Reivich, K., Coulter-Heindl, V., Linkins, M., ... Seligman, M. E. P. (2011). Character strengths predict subjective well-being during adolescence. The Journal of Positive Psychology, 6(1), 31-44. doi: 10.1080/17439760.2010.536773

González-Arratia, N. I., \& Valdez, J. L. (2013). Resiliencia: Diferencias por edad en hombres y mujeres mexicanos. Acta de Investigación Psicológica, 3(1), 941-955. doi: 10.1016/S2007-4719(13) 70944-X

González-Arratia, N. I., \& Valdez, J. L. (2012). Optimismo-pesimismo y resiliencia en adolescentes de una universidad pública. Ciencia Ergo Sum, 19(3), 207-214. doi: 20.500.11799/38216

González-Arratia, N. I., Valdez, J. L., \& Zavala, Y. C. (2008). Resiliencia en adolescentes mexicanos. Enseñanza e Investigacion en Psicologia, 13(1), 41-52. doi: 10.0185-1594

González, M. T., \& Landero, R. (2007). Factor structure of the perceived stress scale (PSS) in a sample from Mexico. The Spanish Journal of Psychology, 10(1), 199-206.

Houpy, J. C., Lee, W. W., Woodruff, J. N., \& Pincavage, A. T. (2017). Medical student resilience and stressful clinical events during clinical training. Medical Education Online, 22(1), 1-8. doi: 10.1080/10872981.2017.1320187

John, O. P., \& Soto, C. J. (2007). The importance of being valid: Reliability and the process of construct validation. In R. W. Robins, R. C. Fraley, \& R. F. Krueger (Eds.), Handbook of Research Methods in Personality Psychology (pp. 461-494). New York: Guildford Press

Lent, R. W., \& Brown, S. D. (2008). Social cognitive career theory and subjective well-being in the context of work. Journal of Career Assessment, 16(1), 6-21. doi: 10.1177/1069072707305769

Linley, P. A. (2003). Positive adaptation to trauma: Wisdom as both process and outcome. Journal of Traumatic Stress, 16(6), 601-610. doi: 10.1023/ B:JOTS.0000004086.64509.09

Lopes, V. R., \& Martins, M. C. F. (2011). Validação fatorial da escala de resiliência de ConnorDavidson (CD-RISC-10) para brasileiros. 
Revista Psicologia: Organizações e Trabalho, 11(2), 36-50.

Lü, W., Wang, Z., Liu, Y., \& Zhang, H. (2014). Resilience as a mediator between extraversion, neuroticism and happiness, PA and NA. Personality and Individual Differences, 63, 128-133. doi: 10.1016/j.paid.2014.01.015

Luthar, S. S., Cicchetti, D., \& Becker, B. (2000). The construct of resilience: A critical evaluation and guidelines for future work. Child Development, 71(3), 543-562. doi: 10.1111/14678624.00164

Lyubomirsky, S., \& Lepper, H. (1999). A measure of subjective happiness: Preliminary reliability and construct validation. Social Indicators Research, 46, 137-155. doi: 10.1023/ A:1006824100041

Marrero, R. J., González, J. A., \& Carballeira, M. (2014). Relación entre bienestar subjetivo, optimismo y variables sociodemográficas en estudiantes universitarios de la Universidad de San Luis Potosí en México. Universitas Psychologica, 13(3), 1083-1098. doi: 10.11144/ Javeriana.UPSY13-3.rbso

Masten, A. S. (2007). Resilience in developing systems: Progress and promise as the fourth wave rises. Development and Psychopathology, 19 (3), 921-930. doi: 10.1017/ S0954579407000442

Medina-Mora, M. E., Borges, G., Lara, C., Benjet, C., Blanco, J., Fleiz, C., Villato, J., Rojas, E., Zambrano, J., Casanova, L., \& AguilarGaxiola, S. (2003). Prevalencia de trastornos mentales y uso de servicios: Resultados de la Encuesta Nacional de Epidemiología Psiquiátrica en México. Salud Mental, 26(4), $1-16$.

Monjezi, Z., \& Naderi, F. (2016). The comparison between resilience, responsibility and subjective well-being (SWB) amongst male and female physicians in Ahvaz, Iran. Social Sciences (Pakistan), 11(9), 1999-2005. doi: 10.3923/ sscience.2016.1999.2005

Moral, J. (2019). Revisión de los criterios para validez convergente estimada a través de la Varianza Media Extraída. Psychologia, 13(2), 25-41. doi: 10.21500/19002386.4119

Munévar, F. R., Vargas, L. B., Borda, D. B., Alpi, S. V., \& Quiceno, J. M. (2017). Análisis psicométrico del Connor-Davidson Resilience Scale (CD-RISC 10) en población universitaria colombiana. Psicología desde el Caribe, 34(3), 61-69.

Muñiz, J., \& Hambleton, R. K. (1996). Directrices para la traducción y adaptación de los tests. Pape- les del Psicólogo, 66(1), 63-70.

Muñiz, J. (1999). Teoría Clásica de los Test (2 ${ }^{\text {nd }}$ Ed.). Madrid: Pirámide.

Navarro-Mateu, F., Morán-Sánchez, I., Alonso, J., Tormo, M. J., Pujalte, M. L., Garriga, A., Aguilar -Gaxiola, S., Navarro, C. (2013). Cultural adaptation of the Latin American version of the world health organization composite international diagnostic interview (WHO-CIDI) (v 3.0) for use in Spain. Gaceta Sanitaria, 27(4), 325-331. doi: 10.1016/j.gaceta.2012.06.005

Notario-Pacheco, B., Solera-Martínez, M., SerranoParra, M. D., Bartolomé-Gutiérrez, R., García -Campayo, J., \& Martínez-Vizcaíno, V. (2011). Reliability and validity of the spanish version of the 10-item Connor-Davidson Resilience Scale (10-item CD-RISC) in young adults. Health and Quality of Life Outcomes, 9(63), 1-6. doi: 10.1186/1477-7525-9-63

Palomar, J., \& Gómez, N. (2010). Desarrollo de una escala de medición de la resilienca con Mexicanos (RESI-M). Revista Interdisciplinaria, 27 (1), 7-22.

Peterson, C. (2006). A Primer in Positive Psychology. Oxford: Oxford University Press.

Quezada, L., Landero, R., \& González, M. T. (2016). A Validity and reliability study of the subjective happiness scale in Mexico. The Journal of Happiness \& Well-Being, 4(1), 90-100.

Rodríguez-Hernández, G. (2019). The eudemonic and hedonic role of happiness in a population with high levels of life satisfaction. Revista de Psicología Social, 34(2), 230-255. doi: 10.1080/02134748.2019.1576323

Rodríguez. M. N., \& Ruiz, M. A. (2008). Atenuación de la asimetría y de la curtosis de las puntuaciones observadas mediante transformaciones de variables: Incidencia sobre la estructura factorial. Psicológica, 29(2), 205-227.

Ruiz-Aranda, D., Extremera, N., \& Pineda-Galán, C. (2014). Emotional intelligence, life satisfaction and subjective happiness in female student health professionals: The mediating effect of perceived stress. Journal of Psychiatric and Mental Health Nursing, 21(2), 106-113. doi: 10.1111/jpm.12052

Rutter, M. (2012). Resilience as a dynamic concept. Development and Psychopathology, 24(2), 335-344. doi: 10.1017/S0954579412000028

Smith, G. D., \& Yang, F. (2017). Stress, resilience and psychological well-being in chinese undergraduate nursing students. Nurse Education Today, 49, 90-95. doi: 10.1016/ j.nedt.2016.10.004

Souri, H., \& Hasanirad, T. (2011). Relationship Bet 
Suhr, D. (2006). Exploratory or confirmatory factor analysis. Proceedings from the SAS users group international conference (pp. 200-231). Cary: SAS Institute, Inc.

Tabachnick, B. G., \& Fidell, L. S. (2019). Using Multivariate Statistics $\left(7^{\text {th }}\right.$ Ed.). New York: Pearson.

Tourunen, A., Siltanen, S., Saajanaho, M., Koivunen, K., Kokko, K., \& Rantanen, T. (2019). Psychometric properties of the 10-item ConnorDavidson resilience scale among Finnish older adults. Aging \& Mental Health, 1-8. doi: 10.1080/13607863.2019.1683812

Tugade, M. M., Fredrickson, B. L., \& Barrett, L. F. (2004). Psychological resilience and positive emotional granularity: Examining the benefits of positive emotions on coping and health. Journal of Personality, 72(6), 1161-1190. doi: 10.1111/j.1467-6494.2004.00294.x

Ungar, M. (2008). Resilience across cultures. The British Journal of Social Work, 38(2), 218-235. doi: 10.1093/bjsw/bcl343

Vaughn, L., Gonzalez, J., \& Baker, R. (2001). Microburst teaching and learning. Medical Teacher, 23(1), 39-43. doi: 10.1080/0142159002005569

Vizoso-Gómez, C. \& Arias-Gundín, C. V. O. (2018). Resiliencia, optimismo y burnout académico en estudiantes universitarios. European Journal of Education and Psychology, 11, 47-59. doi: 10.30552/ejep.v11i1.185

Wagner, F. A., González-Forteza, C., Sánchez-García, S., García-Peña, C., \& Gallo, J. J. (2012). Enfocando la depresión como problema de salud pública en México. Salud Mental, 35(1), 3-11.

Widaman, K. F., Little, T. D., Preacher, K. J., \& Sawalini, G. M. (2011). On creating and using short forms of scales in secondary research. In K. H. Trzesniewski, M. B. Donnellan, \& R. E. Lucas (Eds.), Secondary Data Analysis: An Introduction for Psychologists (pp. 39-61). Washington, DC: American Psychological Association. doi: 10.1037/12350-003

Wilson, M. (2005). Constructing Measures. An Item Response Modeling Approach. Mahwah: Lawrence Erlbaum Associates Publishers.

Ye, Z. J., Qiu, H. Z., Li, P. F., Chen, P., Liang, M. Z., Liu, M.L., Yu, Y. L., Wang, S. N., \& Quan, X. M. (2017). Validation and application of the Chinese version of the 10-item ConnorDavidson Resilience Scale (CD-RISC-10) among parents of children with cancer diagnosis. European Journal of Oncology Nursing, 27, 36-44. doi: 10.1016/j.ejon.2017.01. 


\section{Appendix}

Instrucciones. Conteste seleccionando una respuesta para cada enunciado. No hay respuestas correctas o incorrectas; cada persona es distinta y contesta en base a su opinión o percepción personal.

\begin{tabular}{|c|c|c|c|c|c|}
\hline 1 & 2 & 3 & 4 & 5 & 6 \\
\hline Nunca & Casi nunca & A veces & Frecuentemente & Casi siempre & Siempre \\
\hline
\end{tabular}

\begin{tabular}{|c|l|c|}
\hline$\#$ & Enunciado & $\mathrm{Rx}$ \\
\hline 1 & Soy capaz de adaptarme a los cambios & \\
\hline 2 & Puedo manejar lo que se presente & \\
\hline 3 & Trato de ver el lado positivo de los problemas & \\
\hline 4 & Enfrentar el estrés puede fortalecerme & \\
\hline 5 & $\begin{array}{l}\text { Tiendo a recuperarme rápidamente después de la enfermedad o } \\
\text { las dificultades }\end{array}$ & \\
\hline 6 & Puedo alcanzar mis metas a pesar de los obstáculos & \\
\hline 7 & Puedo mantener la concentración bajo presión & \\
\hline 8 & Difícilmente el fracaso me desanima & \\
\hline 9 & Me considero una persona fuerte & \\
\hline 10 & Puedo manejar los sentimientos desagradables & \\
\hline
\end{tabular}

